\title{
Labor Turnover in the Soviet Union
}

The major objective and main content of the policy which our Party consistently implements involves creating for the worker the most pleasant surroundings for work, study, and leisure, in order to develop and utilize his abilities to the fullest.

LEONID BREZHNEV1

In recent years, Soviet officials and scholars have expressed increasing concern about the "lack of discipline" among industrial workers in the USSR. Labor productivity remains low, and it is improving at an unacceptably slow pace. At the same time, "shirking," "idling," on-the-job drunkenness, and industrial accidents are widespread. But the most troublesome manifestation of the Soviet worker's lack of discipline is the high rate of labor turnover.

According to Soviet usage, the term "labor turnover" includes all persons who quit their jobs voluntarily or who are dismissed for violations of the work rules. In the USSR, this means two out of every ten industrial workers and three out of every ten construction workers-figures which have not changed perceptibly over the course of the post-Stalin era (see table 1 ). ${ }^{2}$ This article will explore the factors that have given rise to such a high level of turnover ${ }^{3}$ and will analyze what the authorities are doing to correct it.

Five decades of rapid industrialization, massive rural out-migration, low wages, and organized recruitment of workers have transformed the USSR from a country with considerable labor surpluses into one where the central planners

1. Pravda, April 22, 1970.

2. "Labor turnover" statistics do not include those whose reasons for leaving a job are regarded as "acceptable," for example, those who are drafted into the armed forces, those who are assigned to another place of work by their superiors, those who go on pension, and so forth. See table 1 , notes $a$ and $b$.

3. Because Soviet scholars and officials are virtually unanimous in viewing the level of labor turnover in their country as high, I have followed their lead. It should be noted, however, that turnover rates in the United States are not very different from those in the USSR: during the period 1965-75, for example, 26.7 percent of those employed in manufacturing industries in the United States quit their jobs each year. But the American and Soviet data are by no means fully comparable. The U.S. Bureau of Labor Statistics, unlike its Soviet counterpart, distinguishes among "accessions," "new hires," and "other accessions," as well as "separations," "quits," and "layoffs." Moreover, in the United States, periods of relatively full employment alternate with periods of widespread unemployment, causing considerable fluctuations over time in American turnover rates. (Low levels of turnover-a circumstance toward which Soviet planners strive-are associated in the United States with recession years: when jobs are scarce, workers are less apt to quit; when jobs are more plentiful, turnover rates tend to increase.) For these and other reasons, it is misleading to compare the Soviet and American figures. See U.S. Department of Labor, Bureau of Labor Statistics, Employment and Earnings, 22, no. 22 (May 1976) : 109-11, for the U.S. data and an explanation of the relevant terms. 
Table 1. Labor Turnover and Total Separations of Wagezvorkers in Industry and Construction (USSR), 1950 to 1970 (in percent, as reported)

\begin{tabular}{|c|c|c|c|c|}
\hline \multirow[b]{2}{*}{ Year } & \multicolumn{2}{|c|}{ Industry } & \multicolumn{2}{|c|}{ Construction } \\
\hline & $\begin{array}{l}\text { Labor } \\
\text { turnover } \\
\text { (1) }\end{array}$ & $\begin{array}{c}\text { Total } \\
\text { separations }^{\mathrm{b}} \\
(2)\end{array}$ & $\begin{array}{l}\text { Labor } \\
\text { turnover } \\
(3)\end{array}$ & $\begin{array}{c}\text { Total } \\
\text { separations } \\
\text { (4) }\end{array}$ \\
\hline 1950 & 15 & 30.6 & 18 & 50 \\
\hline 1955 & 19 & 32.2 & 31 & 62 \\
\hline 1956 & 38 & (c) & (c) & (c) \\
\hline 1959 & 19.6 & 32.5 & 40.8 & 83.3 \\
\hline 1960 & 19 & (c) & 41 & (c) \\
\hline 1961 & 20 & (c) & (c) & (c) \\
\hline 1962 & 19.9 & 31.6 & 39.5 & 79.1 \\
\hline 1963 & (c) & (c) & (c) & (c) \\
\hline 1964 & (c) & (c) & 36 & (c) \\
\hline 1965 & 21 & (c) & 34 & (c) \\
\hline 1966 & 21.7 & 31.8 & 38.3 & 76.2 \\
\hline 1967 & 22.1 & 32.7 & 38.2 & 75.3 \\
\hline 1968 & 22 & (c) & 36 & (c) \\
\hline 1969 & 21 & (c) & 35 & (c) \\
\hline 1970 & 21.0 & 30.0 & 31.6 & 66.9 \\
\hline
\end{tabular}

a Labor turnover is defined as the number of workers who quit voluntarily or were fired for infractions of the work rules.

b Total separations includes all of labor turnover, as well as separations attributable to officially "acceptable" reasons--drafted into the armed forces, separation on old-age pension, separation on disability pension, termination of temporary work, organized recruitment (orgnabor), birth of a child, accompanying spouse to another location, enrollment in fulltime study, and transfer to another enterprise at the direction of a superior organizational echelon (G. S. Savosin, Tckuchest' kadrov: Prichiny i preduprezhdenie [Moscow, 1971], p. 28).

c Not available.

Source: Murray Feshbach and Stephen Rapawy, "Labor Constraints in the Five-Year Plan," in Sovict Economic Prospects for the Seventics, Joint Economic Committee, Congress of the United States, 93rd Congress, 1st Session (1973), p. 539.

express fears of an imminent labor shortage. As two Western commentators have observed, the USSR is "faced with a taut manpower supply situation now, and a serious, demographically predetermined downturn in the future new supply of manpower. . . "4 Soviet analysts have addressed themselves to this development with considerable candor. To quote one economist: "limited labor resources are now a fact, and the more rational use of these resources is becoming a burning question."5 Similarly, a Gosplan official has pointed to "the growing deficit in labor resources" and warned that additional sources of manpower supply "have begun to run dry." To be sure, the natural increase in labor resources during the present Five-Year Plan should be adequate to meet the

4. Murray Feshbach and Stephen Rapawy, "Labor Constraints in the Five-Year Plan," in Soviet Economic Prospects for the Seventies, Joint Economic Committee, Congress of the United States, 93rd Congress, 1st Session (1973), p. 544.

5. Izvestiia, September 6, 1974, p. 3. See also Trud, May 11, 1974, p. 2.

6. Planovoe khoziaistvo, 1973, no. 11, p. 17. 
needs of the planners, but a serious problem is likely to arise within a decade. The relatively small generation born in the 1960s will be entering the work force in the 1980s; it will not be sufficiently numerous to replace the much larger generation born during the $1920 \mathrm{~s}$, which will be leaving the work force. ${ }^{\top}$

Given the sharply reduced availability of additional supplies of manpower, prospects for Soviet economic growth now hinge almost exclusively on raising the productivity of labor and capital. Thus, during the most recent Five-Year Plan (1971-75), planners could count on an annual increase in industrial employment of only 1.3 percent-less than half the rate of growth during the years 1950-70. (Approximately 87 percent of the growth of industrial output, 95 percent of the growth in construction output, and 100 percent of the growth in agricultural output were to come from gains in labor productivity.) Realizing that they cannot count on additional labor reserves, and recognizing that workers who are not happy do not work well (if they work at all), the regime has begun to devote serious attention to the problems of industrial morale, labor productivity, and labor turnover. ${ }^{8}$

There is nothing inherently harmful or irrational about workers changing jobs. In a number of respects this process is healthy for both the worker as an individual and for the Soviet system as a whole. In the broadest sense, it indicates at least a partial relaxation of "the dictatorship of the proletariat" in the past two decades. Many of the extraordinarily harsh labor laws of the Stalin era were, of course, repealed shortly after the dictator's death." Since then, workers have been permitted and even encouraged to seek employment opportunities which meet their needs. As a result, they have become increasingly sophisticated and demanding: people who enter the labor force now, especially those with special skills, are said to "behave quite differently than [people] did in the past, when there was no manpower shortage."10

Moreover, when people move from factories or areas with a manpower surplus to enterprises or localities suffering from a shortage of workers, the end result is a gain for all concerned. ${ }^{11}$ Workers attracted by higher wages or other inducements to new enterprises and construction projects, especially to those in remote areas of the USSR, can be put to especially good use. ${ }^{22}$ Thus, efforts to release "superfluous workers" from enterprises for other jobs-for example, through such programs as the Shchekino experiment-can lead to a more rational distribution of the labor force. In fact, official plans called for the

7. Zhurnalist, 1974, no. 4, pp. 73-74.

8. Feshbach and Rapawy, "Labor Constraints." See also Zhurnalist, 1974, no. 5, p. 79; and Planovoe khoziaistvo, 1973, no. 11, p. 16. A few Soviet specialists have challenged the view that the USSR is faced with a labor shortage. Thus the sociologist A. Aitov, pointing to the massive loss of work time caused by population migration and labor turnover, has concluded that, "our labor resources are completely adequate, but they are utilized irrationally" (see Literaturnaia gazeta, August 20, 1975, p. 10).

9. Anne S. Kahl, Labor Law and Practice in the USSR (Washington, D.C.: U.S. Government Printing Office, 1964), p. 22.

10. Isvestiia, September 6, 1974, p. 3 .

11. See, for example, Sovetskoc gosudarstvo i pravo, 1974, no. 11, p. 66.

12. Ekonomika i organizatsiia promyshlennogo proizvodstva, 1974, no. 1, pp. 125-30 (translated in Current Digest of the Soviet Press, 26, no. 36 [1974]: 3). 
Table 2. Labor Turnover among Industrial Workers by Union Republic (USSR), 1967 (in percent)

\begin{tabular}{ll}
\hline USSR & 22.1 \\
Armenia & 31.7 \\
Azerbaidzhan & 30.2 \\
Belorussia & 18.6 \\
Estonia & 23.8 \\
Georgia & 30.6 \\
Kazakhstan & 32.7 \\
Kirghizia & 35.1 \\
Latvia & 25.3 \\
Lithuania & 26.5 \\
Moldavia & 36.3 \\
RSFSR & 21.4 \\
Tadzhikistan & 39.8 \\
Turkmenistan & 36.7 \\
Ukraine & 19.9 \\
Uzbekistan & 31.3 \\
\hline
\end{tabular}

Sotirce: L. M. Danilov, Dvishenic rabochikh kadrov v promyshlennosti (Moscow, 1973), p. 128.

reassignment of $1,600,000$ industrial workers to other plants during the period 1971-75. This represents three-fourths of the manpower requirements at new industrial enterprises. ${ }^{13}$

Labor turnover also can serve as a cue for planners. As a Soviet sociologist has pointed out: "If . . . people leave an enterprise in which there is no future, this serves as a signal indicating the need to modernize it."14

But if some level of dissatisfaction and turnover is inevitable and even desirable, too much of either can present significant problems. There is widespread agreement that the level of turnover which prevails in the USSR today is not within acceptable limits. Some have termed it "harmful, not justified by any objective need, . . . a barrier to the progress of society."15 Others have referred to the problem as "a disease . . ., a social evil which requires opposition on a joint and organized basis."16 In some republics (especially in Central Asia and Transcaucasia) and in some industries (especially the food industry), the prevailing levels of turnover are alarmingly high (see tables 2 and 3 ).

Whether or not "surplus mobility" (as excessive turnover in the USSR is called) is, indeed, "a disease" or "an evil," its economic consequences greatly disturb the government. Workers who quit their jobs do substantial damage to the national economy, and they create economic problems for the enterprises they leave, for the enterprises they join, and for themselves and their families as well. The costs involved are of three kinds.

First, turnover leads to significant losses of work time for both people and machinery. Many of those who move from job to job spend lengthy periods of

13. Ibid.

14. Zhurnalist, 1973, no. 11, p. 12.

15. Ibid.

16. Sotsialisticheskaia industria, January 19, 1971, p. 3. 
Table 3. Labor Turnover in Industry (USSR), 1960 and 1970 (in percent of turnover rate for industry as a whole)

\begin{tabular}{lrr}
\hline & 1960 & 1970 \\
\cline { 2 - 3 } Industry as a whole & 100.0 & 100.0 \\
Coal industry & 130.7 & 71.3 \\
Ferrous metal industry & 49.2 & 72.6 \\
Chemical and petrochemical industry & 57.7 & 86.8 \\
Machine-building and metal-working industry & 71.4 & 86.3 \\
Timber, woodworking, and pulp-and-paper industry & 153.4 & 118.9 \\
Building materials industry & 194.7 & 138.7 \\
Light industry & 81.5 & 102.8 \\
Food industry & 188.4 & 150.9 \\
\hline
\end{tabular}

Source: Danilov, Dvizhenie rabochikh kadrov v promyshlennosti, p. 129.

time without any employment whatsoever. Even if these individuals are not officially classified as "unemployed," they clearly "are not working, but only consuming."17 Surveys conducted in various regions of the USSR indicate that, on the average, persons who leave their jobs spend one to two months finding new work. A 1971-72 study of industrial enterprises and construction trusts in the RSFSR, for example, found that such people lost an average of 26 working days before finding new jobs. ${ }^{18}$ Data from L'vov province show that workers who quit lose between 25 and 70 days of work, while studies in Moscow and Armenia indicate average losses of 49 days and 73 days, respectively. ${ }^{19}$ A more detailed survey, conducted in Lithuania in the mid-1960s, revealed a particularly striking pattern of work time losses. Researchers found that only 11.3 percent of those who changed their place of work did so without a break in employment. One-fourth (24.6 percent) of those who changed jobs were out of work for a week, while slightly more (25.4 percent) were unemployed for a period of one week to one month. An even larger number (29.7 percent) were without jobs for periods varying between one month and a year. Nine percent were unemployed for more than a year. ${ }^{20}$

The overall impact of this work time loss is immense. According to a Gosplan official, the total loss attributable to labor turnover throughout the country in 1972 was approximately four billion rubles. ${ }^{21}$ For the RSFSR alone, the annual loss has been estimated at more than 3 billion rubles. ${ }^{22}$ At least three and a half million people change jobs each year in industry and construction in the RSFSR, and the losses caused by their being out of work are equivalent to a year's work time for more than 400,000 people. ${ }^{23}$

17. Narodnoe khoziaistvo Kazakhstana, 1974, no. 1, translated in Joint Publications Research Service (hereafter JPRS), no. 61953, p. 16.

18. Planovoe khoziaistvo, 1973, no. 6, p. 119.

19. G. S. Savosin, Tekuchest' kadrov: Prichiny i preduprezhdenie (Moscow, 1971), p. 8, n. 1.

20. Tekuchest' kadrov v promyshlennosti (Vilnius, 1967), pp. 77 and 79.

21. Planovoe khoziaistvo, 1973 , no. 11, p. 20.

22. Planovoc khoziaistvo, 1973, no. 6, pp. 119-20.

23. Trud, May 11, 1974, p. 2. For the USSR's economy as a whole, work time losses 
Furthermore, during the period of adaptation to a new job, the worker is likely to perform less efficiently and less productively than his or her fellow workers. To master new machinery and new production techniques, to become familiar with new working conditions, and to "fit in" with a new labor collective takes time-and wastes money. ${ }^{24}$ Labor productivity among people who change jobs is usually some $25-30$ percent below normal in the period immediately before departure and in the first two months on the new job; during the third month, productivity is 3-5 percent below normal. Only in the fourth month does it return to the appropriate level. ${ }^{25}$

Second, turnover involves a serious waste of resources for manpower training and retraining programs. According to Soviet estimates, between 40 percent and 75 percent of those who change their place of work change their occupation as well. Thus, funds initially spent to provide people with specialized skills have been largely wasted, and new funds must be spent for retraining purposes. $^{20}$

Finally, low morale and high labor turnover lead to other kinds of problems that are less directly, but just as powerfully, related to the economy. They contribute to on-the-job injuries (through negligence or lack of familiarity with machinery), introduce uncertainties into the housing market, cause a deterioration in "the psychological climate of work collectives," and lead to violations of "labor and social discipline." This last problem seems to be of particular concern; Soviet studies emphasize the adverse effect that turnover has on labor discipline. Sample surveys indicate that most violators of labor discipline have worked at a given enterprise for only a brief period of time. A number of analysts have stated that people who change jobs often have not been exposed to the healthy influence of a collective long enough to internalize the values of discipline, selfdiscipline, and cooperation. ${ }^{27}$

All other things being equal, a worker who has been associated with a particular enterprise for a long period of time is more productive than a man or woman newly arrived on the job. Indeed, according to some estimates, upward of 75-80 percent of workers who do not fulfill their production quotas are people who have worked at their enterprise for less than a year. The available evidence also suggests that "unstable cadres" (the term for workers who change jobs frequently) are responsible for poor workmanship. A study of workers who had been employed at one Soviet enterprise for only a few months found that 1.5-5 percent of their output was defective. Among "cadre workers," that is, among those who had been on the job for many years, the figure was only $0.2-0.5$ percent. Approximately 60 percent of all defective goods produced at this factory were attributed to workers who had been employed there for less than a year. ${ }^{28}$

attributable to turnover have been likened to the "evaporation" of 1.5 million people (Literaturnaia gazeta, August 20, 1975, p. 10).

24. Narodnoe khoziaistvo Kazakhstana, 1974, no. 1, p. 16.

25. Feshbach and Rapawy, "Labor Constraints," p. 541. See also Ekonomicheskaia gazeta, 1974, no. 31, p. 7 .

26. Narodnoe khoziaistvo Kazakhstana, 1974, no. 1, p. 20; and Tekuchest' kadrov v promyshlennosti, p. 75.

27. See, for example, Narodnoe khoziaistvo Kazakhstana, 1974, no. 1, pp. 19 and 20.

28. Savosin, Tekuchest' kadrov, pp. 5 and 7. 
The explanation for this involves more than the fact that "cadre workers" improve their skills with additional work experience. Increased tenure on the job also seems to change a worker's psychological predispositions and his morale. Once he adapts to a new collective and decides to remain-especially if he is happier there than at his previous place of employment-he tusually develops new work attitudes and habits. When a feeling of "belonging" and a desire to cooperate with his fellow workers are combined with the higher skill levels that come with additional experience on the job, the result is likely to be more productive labor. ${ }^{29}$

Until recently it was all but impossible to assess the relative significance of the various factors that produce labor turnover. Even now, any effort to do so confronts formidable obstacles, because there are large gaps in our data base. Westerners cannot carry out empirical research projects in the USSR, and Soviet discussions of morale and labor turnover often are of questionable value. Although some Soviet studies are methodologically sound, others are completely unscientific. The sampling procedures and interview schedules which are used are not always made clear and, when they are, they often fall short of methodological rigor. Many of the "studies" also appear to serve more of an inspirational than an informative function, and even the most scholarly Soviet treatments of industrial morale usually contain an element of propaganda. ${ }^{\mathbf{3 0}}$

Some Soviet scholars and administrators have been careless in identifying the causes of labor turnover. Their classification of reasons for people changing jobs frequently have involved little more than entering on a worker's labor book a notation such as "left at his/her own request." Formulations of this kind do not really explain anything. As G. S. Savosin writes, the fact of leaving a job of one's own volition is "only the reflection in people's consciousness of those material conditions in which they live and work." 31

"Reasons" traditionally cited by workers for a decision to change jobs, such as "departed for other work" or "moved to another locale," are equally vague. In reality, a decision to move is generally "a consequence of a whole series of factors which determine one's motive for quitting." 32 Furthermore, people's responses to a sociologist's questionnaire do not always reveal their true feelings. For example, it seems that a large proportion of those who leave their jobs do so once they are passed over for a promotion they feel they deserve. ${ }^{33}$ Many of these people say that they quit because they were "dissatisfied with working

29. See the remarks of A. Aitov, quoted in ibid., p. 5. See also Sovctskaia pcdagogika, 1974, no. 9, p. 74.

30. For a discussion of some of the limitations of industrial sociology in the USSR, see Lewis S. Feuer, "Problems and Unproblems in Soviet Social Theory," Slavic Review, 23, no. 1 (March 1964) : 120-21.

31. Savosin, Tekuchest' kadrov, p. 22. According to a prominent legal scholar, many of those who leave a job "at their own request" are in fact fired because of a drinking problem (Iu. M. Tkachevskii, Pravovye mery bor'by s p'ianstvom [Moscow, 1974], pp. 24, 25, 67).

32. M. T. Iovchuk and L. N. Kogan, eds., Dukhovnyi mir sovetskogo rabochego (Moscow, 1972), p. 255; and Savosin, Tekuchest' kadrov, p. 23.

33. Iovchuk and Kogan, Dukhovnyi mir, p. 267. 
conditions," whereas it is more likely that they left because they felt hurt and rejected, or were fearful of being embarrassed in front of their fellow workers. ${ }^{34}$

There are, of course, many Soviet sociological studies which offer a rich array of data and enable us to identify the principal causes of labor turnover. Obviously, many features of the Soviet economic and political system help to bring about worker dissatisfaction and turnover. For example, the Soviet system of incentives and rewards produces numerous irrationalities and distortions which trouble workers. Many people express their grievances with this system by quitting their job-sometimes because they are convinced that things will be better elsewhere, and sometimes because they are frustrated with the steady stream of exhortations directed at them. ${ }^{35}$ Deficiencies in regional planning also have created problems. In some areas of the country, planners have inadvertently created "cities of brides" and "cities of grooms"-cities with a pronounced disproportion between the number of male and female workers. The difficulties involved in trying to find marriage partners-especially for women employed in textile mill towns in the RSFSR and for men employed in heavy industry in the Urals or Siberia-leave many with no other choice than to quit their job. ${ }^{36}$ Similarly, disagreeable climatic conditions, such as those which prevail in Central Asia and Siberia, contribute to higher than average rates of turnover ${ }^{37}$ According to recent Soviet studies, however, the principal factors leading to job dissatisfaction and turnover are real or perceived shortcomings in working conditions, pay rates, housing arrangements, and preschool facilities. I will deal with each of these in turn.

The most important factor in labor turnover involves what Soviet sources refer to as "dissatisfaction with working conditions." A number of surveys taken over the past decade indicate that approximately one-third of all workers who change jobs do so because of this concern. ${ }^{38}$ The term, unfortunately, is a rather elastic one, and it is not used in precisely the same way by all commentators. Generally speaking, however, it includes dissatisfaction with dangerous working conditions, with heavy physical labor, with boring work assignments, and with flaws in "the organization of labor" (that is, unpredictable or erratic work schedules-frequent periods of idleness, followed by episodes of "storming").

Leading party and trade union officials frequently comment on the problem of inadequate sanitary facilities in industry. In 1972, the chairman of the Armenian Trade Union Council complained about new production facilities being put into operation even though plant officials were aware that health regulations were being violated. ${ }^{39}$ Other commentators have pointed to "shortcomings and unsolved problems in labor safety procedures" in Tadzhikistan, Kirghizia,

34. Sotsialisticheskaia industriia, January 10, 1974, p. 2.

35. See Pravda, January 18, 1975, p. 2; and Literaturnaia gazeta, August 20, 1975, p. 10.

36. See, for example, Pravda, March 26, 1975, p. 2.

37. See Sovetskoe gosudarstvo i pravo, 1974, no. 11, pp. 66-70.

38. See Iovchuk and Kogan, Dukhormyi mir, p. 254.

39. Kommunist (Erevan), February 2, 1972, p. 2. 
Lithuania, Latvia, Estonia, and elsewhere. ${ }^{40}$ They argue that the government, by creating "dangerous labor conditions" in certain enterprises, fosters precisely those conditions which lead to turnover. ${ }^{41}$ Similarly, in factories or shops where noise levels exceed permissible norms, or where air purification equipment is inadequate or nonexistent, worker dissatisfaction is usually far greater than average. As a result, turnover rates also tend to be higher. ${ }^{42}$

Industries and plants with a relatively low level of mechanization, where heavy manual labor is the norm, also experience a relatively high rate of turnover. ${ }^{43}$ Thus, because the number of workers employed at manual labor is so great, most industries and plants are severely affected. (As recently as 1972, approximately 50 percent of all Soviet industrial workers were performing unmechanized labor ${ }^{44}$ ) Middle-aged and older workers, primarily those with less than eight years of schooling, are heavily overrepresented in this group, although many youths are included as well. ${ }^{45}$ All of these people are more apt than their skilled colleagues to become dissatisfied with their jobs and quit. Indeed, according to a Leningrad study, only 20 percent of workers engaged in unskilled labor express satisfaction with their jobs, whereas among highly skilled workers, the proportion is more than 50 percent. ${ }^{46}$

An even more basic source of dissatisfaction with working conditions is the widespread practice of compelling people to work overtime and on their days off. Legally, a person is required to work at other than his or her regularly scheduled times only in case of a natural disaster or in a genuine economic emergency, and even then only with the permission of the local trade union committee. In practice, however, the law is violated regularly throughout the Soviet Union. ${ }^{47}$

Some Soviet analysts have argued that the main reason for labor turnover is dissatisfaction with pay. In one study of 5,000 young factory workers who had changed jobs, this factor was cited more frequently than any other (by 14 percent of the sample). ${ }^{48}$ Even more striking, a Lithuanian survey revealed that more than one-fourth ( 28 percent) of all workers who quit were seeking higher wages in a new job. ${ }^{49}$ However, the significance of the Lithuanian findings is not altogether clear. Careful analysis of the data indicates that a large proportion of workers who attributed their decision to leave to dissatisfaction with pay scales

40. See, for example, Kommunist Tadshikistana, February 5, 1972, p. 2; Sovetskaia Kirgisiia, January 27, 1972, p. 3; Sovetskaia Litva, February 1, 1972, p. 2; Sovetskaia Latviia, January 28, 1972, p. 2; Zaria vostoka, May 7, 1972, p. 2; and Sotsialisticheskaia zakonnost', 1974 , no. 3, p. 22.

41. Zaria vostoka, September 27, 1973, p. 1; and Kommunist (Erevan), October 27, 1972, p. 2.

42. Savosin, Tekuchest' kadrov, p. 33; Zaria vostoka, May 7, 1972, p. 2; Zaria vostoka, September 27, 1973, p. 1; and Trud, April 11, 1975, p. 2.

43. Tekuchest kadrov v promyshlennosti, p. 69.

44. Molodoi Kommunist, 1972, no. 6, p. 64; and Izvestiia, August 16, 1974, p. 3.

45. Savosin, Tekuchest' kadrov, pp. 34-35.

46. Izvestiia, March 3, 1970, p. 3.

47. Trud, April 11, 1975, p. 2; and Kommunist Latvii, 1972, no. 2, p. 9.

48. L. Ananich and L. Bliakhman, Zavodskaia molodezh': Professional'nye interesy (Moscow, 1971), p. 128.

49. Tekuchest kadrov v promyshlennosti, p. 4. Men are far more apt than women to cite inadequate wages as the principal reason for quitting a job (see Sotsialisticheskaia industriia, July 24, 1974, p. 3). 
were really motivated by other concerns. A worker's pay can and often does fluctuate dramatically over a brief span of time in Soviet industry because of alternating periods of idleness and "rush work." Whether this alternation is caused by inept management, failures in the supply system, mechanical breakdowns, or some combination of these factors, it results in disruptions of wage payments-and therefore in worker dissatisfaction and turnover. ${ }^{50}$

To what extent, therefore, does the lure of the ruble motivate people to change jobs? The evidence here is confusing and (at least at first glance) even contradictory. While some workers are anxious to shift from lower-paying jobs to positions that pay better, labor turnover rates are generally higher in industries and enterprises that have higher pay scales. For example, the average wage in the fishing industry is the second highest (after coal mining) in the country. Its turnover rate is also one of the highest. (One study places the fishing industry in fourth place in rate of turnover.) Data from Kuibyshev province and elsewhere also show a strong link between wage levels and turnover. At industrial enterprises in Kuibyshev, turnover is highest at precisely those plants which pay the highest wages. Figures obtained from a survey of Leningrad factories show a similar pattern. ${ }^{51}$

These puzzling findings can, however, be explained quite readily. In the first place, pay rates for workers in different factories who perform the same tasks vary widely, and such anomalies encourage job-hopping. ${ }^{52}$ Equally important, the wages of those who leave a particular factory tend to be far less than the wages of those who remain. It is the younger workers-those with less experience and lower qualifications, who are discomfited by the presence of so many highly-paid colleagues-who quit. ${ }^{53}$

In some areas of the country, especially in the Far North and Siberia, the shortage of adequate housing is a crucial consideration leading to turnover. ${ }^{\overline{4}}$ Most studies, however, assign a rather modest role to the housing problemperhaps because it affects people everywhere in the USSR. A survey taken in Kaluga, for example, found that only 3.8 percent of all workers left their jobs because they were dissatisfied with their housing and were convinced that their situation would not improve in the near future. Most workers who decided to quit cited other concerns more closely linked to their jobs. ${ }^{55}$

Some people obviously are more likely than others to be distressed about poor housing. Residents of workers' dormitories (presently some 3.5 to 4.0 million people, and growing by 200,000 a year) are perhaps the most frustrated of all. Studies have shown that approximately 80 percent of dormitory residents are dissatisfied with their living conditions; almost 40 percent of this group leave the dormitories within a year, while only half this number stay on for

50. Tekuchest' kadrov v promyshlennosti, p. 11. p. 133.

51. L. M. Danilov, Dvizhenie rabochikh kadrov v promyshlennosti (Moscow, 1973),

52. Tekuchest' kadrov $v$ promyshlennosti, p. 41.

53. Pravda vostoka, October 1, 1974, p. 3.

54. See, for example, Gidroliznaia i lesokhimicheskaia promyshlennost', 1973, no. 4, in JPRS, no. 29607, p. 16.

55. Trud, March 1, 1974, p. 2. 
more than three years. When they move out of the dormitory, they almost always leave their jobs. ${ }^{56}$

The number of people who attribute their decisions to leave a job to the shortage or inadequacy of preschool facilities varies considerably from region to region. More important, the problem of gaining access to day-care facilities affects certain groups more than it does others. It obviously concerns those with families more than it does single men or women, and it is of particular concern to married women. When couples find out that there is no one to care for their child or children, it is almost always the wife who gives up her job. For example, a survey of one Moscow factory revealed that although only 2.8 percent of all those who quit their jobs did so because of the shortage of day-care facilities, the figure among women was twice as high- 5.7 percent. ${ }^{57}$

The Lithuanian study produced results that were even more striking. Investigators found that 20.1 percent of all women who gave up their jobs did so because of the shortage of children's institutions. Approximately one-third (35.1 percent) of the women were out of work for more than six months, as opposed to only 8.5 percent of the men. More than half ( 57.1 percent) of the women who experienced prolonged absence from work cited the need to care for their children in explanation..$^{58}$

The problem of preschool facilities has been termed "one of the most important reasons for women losing work time and for turnover among them," ${ }^{59}$ and it is likely to remain so for some time to come. The industries which traditionally have attracted female workers-especially enterprises under the Ministry of Food Industry and the Ministry of Light Industry-have been particularly negligent in providing working mothers with adequate facilities for their children. In 1972, for example, these ministries built only about 50 percent of the preschool institutions called for in the Plan. ${ }^{60}$

The factors which help to explain worker dissatisfaction and labor turnover are closely interrelated; they overlap, reinforce, and even "explain" each other. Thus, those individuals who leave a job because they are dissatisfied with working conditions tend to be dissatisfied with pay and housing as well. Similarly, those who leave jobs because of a desire "to move to another locale" turn out to be essentially the same people who quit because they find their working conditions unsatisfactory. In the classic Sverdlovsk study, 81 percent of those who quit "in order to change their place of residence" were manual workers, while only 2.4 percent were involved with mechanized labor. Among workers who quit because of dissatisfaction with working conditions, the figures were very similar: 65 percent were manual workers and 4.3 percent were engaged in mechanized labor. The real, operative motive in both circumstances was "undoubtedly the workers' dissatisfaction with heavy physical labor, their desire to move to enterprises with better working conditions." ${ }^{11}$

56. See Literaturnaia gazeta, October 2, 1974, p. 12; and Komsomol'skaia pravda, August 20, 1974, p. 2.

57. Savosin, Tekuchest' kadrov, p. 35.

58. Tekuchest' kadrov $v$ promyshlennosti, pp. 77 and 79.

59. Ibid., p. 79.

60. Uchitel'skaia gazeta, February 24, 1974, p. 1; and Komsomol'skaia pravda, March 28,1974, p. 2.

61. See Iovchuk and Kogan, Dukhovnyi mir, pp. 257 and 259. 
Younger workers in the Soviet Union are a special case, for they are far more apt than their older colleagues to quit their jobs. In the RSFSR, for example, workers under thirty years of age are responsible for 60-65 percent of all labor turnover, and the situation in other republics is comparable. ${ }^{62}$

Many circumstances combine to produce high rates of turnover among younger men and women. Of these, six are of particular significance. First, on the most obvious level, immaturity leads many of the young people to quit for no apparent reason. Younger workers without any family ties are especially apt to seek individual fulfillment by moving from job to job. They are sometimes said to manifest "romantic illusions" and even a kind of "infantilism." 63 As one sociologist has explained it:

the basic factor in stability is an objective one, social experience and social maturity. The young person is convinced that the grass is greener on the other side of the fence, and he tries to find himself, jumping from place to place, sometimes causing harm to industry and even more to himself. ${ }^{84}$

Second, it is sometimes difficult or even impossible for young people to combine work with study. In enterprises where a large number of youths want to continue their schooling, it may not be easy to arrange a work schedule that is convenient for them and at the same time acceptable to the plant administration. Since many prospective students are unable to work the night shift, management is compelled either to grant leaves to an excessive number of workers at one time, or else to dismiss some of them. This circumstance frequently leads to feelings of frustration among young workers and leads many of them to quit. ${ }^{65}$

Third, young people are likely to have psychological problems adapting to their new roles as industrial workers. Youngsters everywhere seem to be insecure ; in the Soviet Union, as elsewhere, they tend to be easily hurt by insensitivity on the part of their fellow workers or the plant manager. Generally speaking, new personnel are ignored or "overlooked" by their colleagues, and this inevitably generates thoughts about quitting. ${ }^{66}$ Indeed, according to a Leningrad party official, the principal reason for young people leaving their jobs is "inadequate attention on the part of the administration and public organizations, and the inability or lack of desire to 'bother' with each newcomer." 67

A fourth consideration involves those workers who are assigned to work in a field other than that in which they were trained. Some of these youths have spent years acquiring a specialty, but upon graduation find themselves relegated to unskilled or semiskilled operations. Others know little if anything about the job when they take it, and are unclear about their own needs and ambitions. Both groups eventually become bored or unhappy. One study cites "major errors" in placing skilled workers and criticizes the fact that they are "used incorrectly" at enterprises. It points out that although Soviet law requires managers to give

62. Planovoe khoziaistvo, 1973, no. 6, p. 119 ; Molodoi Kommunist, 1972, no. 6, pp. 59-64.

63. Zhurnalist, 1973, no. 11, p. 14.

64. Ibid., p. 13.

65. See Krasnaia zvezda, March 7, 1974, p. 1; and Savosin, Tekuchest' kadrov, p. 34.

66. Ekonomicheskaia gazeta, 1973, no. 48, p. 6.

67. Pravda, March 8, 1974, p. 2. See also Sovetskaia Kirgiziia, September 28, 1974, p. 3. 
graduates of technical and vocational schools jobs in their fields of specialization, there continue to be "frequent instances in which young men and women who earned high grades at school are used in jobs not related to their professions or even in auxiliary operations." 68 The point is an important one, for approximately one out of every five workers under thirty does not do the work for which he or she was trained. ${ }^{69}$

Fifth, many young people who go to work do so unwillingly, usually because they have failed to gain admission to a higher educational institution. Secondary school graduates are generally uninterested in manual labor or jobs in the service sector ; most want to pursue their education in order to join one of the more prestigious professions. But the number of places available in vuzy is far less than the demand. Because of this disparity, many pupils "go into production work under pressure and consider such work to be temporary."70

Soviet surveys have found that approximately 80 percent of all secondary school seniors hope to enter an institution of higher learning after graduation, but only about half of them succeed in this quest. Many of those who try and fail accept some sort of meaningless job, with the intention of leaving at the first opportunity. When the job does not satisfy them, "they look around again and find someplace else to work."71 A study of seniors in general secondary schools in Leninabad, Tadzhikistan, for example, found that 87 percent of the youngsters intended to enter higher educational institutions; at the beginning of the next academic year, however, only 44 percent had actually entered a vuz. Moreover, while only 6 percent of the graduates announced an intention to work in production, 40 percent of them had to take a production job. ${ }^{72}$

Finally, younger workers are subjected by managers to certain direct and invidious forms of discrimination. Some plant officials have been accused of dividing the Labor Code into "major" and "minor" sections and paragraphs: "those that deal with the rights of the younger workers become unimportant to them."73 For example, younger workers, because they have little or no seniority, often are compelled to work on the second or third shift and generally are provided with the least adequate housing. Studies of young workers in various industries indicate that such indifference on the part of managers is widespread. ${ }^{74}$

Managerial indifference, which affects workers of all backgrounds, has particularly severe consequences for younger people, and perhaps even a traumatic impact on minors. At some enterprises, people under the age of eighteen are accepted for work without the required preliminary medical examination, and they are denied regular annual and supplementary leaves. Instances of minors being obliged to work overtime, at night, or on their days off-in direct violation of the law-are also said to be widespread. In addition, there are frequent press

68. Krasnaia zvezda, March 7, 1974, p. 1.

69. Planovoe khoziaistvo, 1973, no. 6, p. 120.

70. Sovetskaia pedagogika, 1972, no. 7, p. 18. See also Komsomol'skaia pravda, September 21, 1972, p. 4 ; and Sovetskaia pedagogika, 1974, no. 9, p. 71.

71. Sovetskaia Litva, September 27, 1971, p. 2.

72. Kommunist Tadzhikistana, November 4, 1969, p. 3.

73. Komsomol'skaia pravda, December 25, 1973, p. 2.

74. Turkmenskaia iskra, May 12, 1973, p. 2; Sovetskaia Kirgiziia, January 27, 1972, p. 3 ; Krasnaia zvezda, March 7, 1974, p. 1; and Trud, December 12, 1973, p. 4. 
reports of minors being illegally hired or fired. According to the law, anyone under the age of sixteen who has not graduated from an eight-year school cannot be hired or fired without the approval of the local Commission on Youth Affairs. There are reports, however, of youngsters being dismissed "by a wave of the director's pen," that is, without the approval of the youth commission, the trade union committee, or the Komsomol committee. ${ }^{75}$

Soviet authorities, both national and local, are just beginning to deal seriously with the problems of industrial morale and labor turnover. They employ a variety of economic, educational, and organizational measures, ranging from discussions with individual workers who find their job unsatisfying to elaborate and comprehensive programs of "social planning." "76 Most of these "programs," however, still involve more rhetoric than action.

One of the most popular approaches to solving the labor problem is better vocational guidance for youngsters. Although schooling in the USSR traditionally has involved some emphasis on polytechnic education, existing programs have come under increasing attack. In recent years, there has been some effort to expand classroom propaganda (and even preschool lessons) on the merits of various trades. The authorities have also encouraged visits to schools by leading workers and officials, and have attempted to establish special groups of "vocational advisers" under local government agencies. ${ }^{77}$

The logic behind these measures is clear. As one Soviet teacher said: "Assisting young people in selecting an occupation is a matter of great state importance."78 But precisely because this is true, much more needs to be done. Even today, graduates of technical trade schools tend to feel that they are "birds of passage"; they are uncertain about their ultimate career objectives and are cavalier about fulfilling their job responsibilities. ${ }^{79}$ Indeed, there is no real system of vocational guidance for the young. To quote one government official, "all work in this area is still largely unplanned and of an unsystematic character." 80

A second widespread approach is that of providing additional incentives for the best workers and adopting sterner policies toward those who violate "labor discipline." Those who work conscientiously are more likely to be promoted and are given priority in the allocation of important perquisites. In the words of the 1970 USSR Labor Code:

workers and employees who have successfully and conscientiously performed their duties shall be granted priority and privileges in the areas of social, cultural, housing, and personal services (trips to sanitariums and rest

75. Komsomol'skaia pravda, December 25, 1973, p. 2; and Sotsialisticheskaia industriia, March 8, 1974, p. 2.

76. See, for example, Pravda, September 10, 1970, p. 2; Savosin, Tekuchest' kadrov, p. 26; and Sotsialisticheskii trud, 1972, no. 4, in JPRS, no. 56338, pp. 18-19.

77. See Sotsialisticheskii trud, 1971, no. 8, pp. 82-89; and Shkola i proizvodstvo, 1974, no. 3, in JPRS, no. 61981, pp. 5-9.

78. Kommunist Tadzhikistana, November 4, 1969, p. 3.

79. Pravda Ukrainy, March 24, 1974, p. 2.

80. Moskovskaia pravda, March 29, 1974, p. 2. 
homes, improvements in housing conditions, etc.). Such workers shall also be given priority in job advancement. . . . ${ }^{81}$

Some factories pay special bonuses to workers who remain in service at the enterprise for a certain number of years, ${ }^{82}$ while other plants give some sort of medal or certificate to these individuals. People with many years of "uninterrupted work" (nepreryvnyi stazh) may be honored as "Veterans of Labor" or be singled out "For Ten Years of Irreproachable Labor." ${ }^{33}$

"Rolling stones" and "slackers," on the other hand, are deprived of bonuses and passes to rest homes, are passed over for promotions, are provided with improved housing slowly (if at all), and are subjected to other privations as well. These measures are said to be especially effective against those who "chase after an easy ruble, in disregard of society's and the collective's interests." 84

It is not clear, however, that such an approach helps to raise industrial morale or reduce turnover. Awarding workers at some plants a special bonus for ten years of continuous service does not alleviate the basic problem of people changing jobs after only a few months. Moreover, this technique may frustrate and alienate those who have worked conscientiously at the enterprise for a lengthy period, if they have not worked long enough to qualify for a bonus or certificate. $^{85} \mathrm{~A}$ Soviet specialist in industrial sociology has declared that the prevailing system of moral incentives "needs to be drastically revised," 86 while others have argued that the incentive system is just as likely to low'er morale as to raise it. To quote a Soviet philosopher: "The fear of not receiving a reward suffocates a worker and 'imprisons' his initiative. . . ."87

Authorities are also trying to make the work environment more appealing and to reduce the incidence of industrial accidents. In the words of a trade union publication, the ultimate objective is "to turn all of our plants and factories into clean light laboratories, creating all the conditions for high output and creative labor by the Soviet people." 88 Although this goal remains unrealized, a great deal has been done in recent years to improve the work environment of Soviet citizens.

At a number of enterprises, music is played during working hours, walls and ceilings are decorated with bright and appealing colors, workers are provided with fashionable work clothing, and recreation centers or tea rooms have been installed. Some factories, in addition to the usual range of amateur theatricals and sports contests, now arrange excursions or provide other facilities for their workers, in an effort to keep them happy and productive. ${ }^{89}$ At the same time,

81. Cited in Feshbach and Rapawy, "Labor Constraints," p. 543. See also Ekonomicheskaia gazeta, 1974, no. 31, p. 7 .

82. See Pravda, August 10, 1973, p. 3; and Sovetskaia iustitsiia, 1974, no. 18, p. 19. See also Leonard J. Kirsch, Sovict Wages (Cambridge, Mass.: MIT Press, 1972), p. 155.

83. Stroitel'naia gazcta, February 28 , 1975, p. 3, translated in JPRS, no. 64507, p. 5; Planovoe khoziaistvo, 1973, no. 11, p. 21; Sovetskaia iustitsiia, 1974, no. 18, p. 20.

84. Izvestiia, September 28,1973 , p. 3.

85. Ekonomicheskaia gazeta, 1973, no. 48, p. 6.

86. Zaria vostoka, July 25,1973 , p. 2.

87. Literaturnaia gazeta, May 16, 1973, p. 10.

88. Sovetskie profsoiuzy', 1974, no. 23, p. 35.

89. See Litcratumaia gazcta, May 16, 1973, p. 10; and Partiinaia zhizn', 1973, no. 5, pp. $45-49$. 
allocations for better lighting, ventilation systems, air conditioning, humidifiers, dehumidifiers, and new safety devices have been increased sharply. During the period 1971-73, for example, more than four billion rubles were spent for "labor protection," almost twice as much as was spent during the corresponding period of the previous Five-Year Plan. ${ }^{00}$

Another measure designed to lower labor turnover has been the establishment of special job-placement centers in many Soviet cities. The purpose of these centers is "systematically to reallocate labor resources among enterprises, to shorten the amount of time it takes to find a job, and to reduce labor turnover," or, more simply, "to save time, energy, and nerves, while at the same time saving valuable work days for industry." $"$ By the end of 1973, more than two hundred of these bureaus had been opened in the USSR, approximately half of which were located in the RSFSR. ${ }^{92}$

According to official claims, these employment centers have proven to be extremely helpful in raising industrial morale and lowering turnover. But the available data are less clear. Certainly the existence of employment bureaus has helped to reduce the time lost by individuals who change jobs; they have also brought about a decline in the number of people who change their specialization upon moving to a new job. By providing citizens with comprehensive and reliable information about such matters as working conditions, wages, housing, and daycare facilities at various enterprises, the task of finding a new job is made more rational. And, by helping people find "the right job," employment bureaus increase the likelihood that workers will be happy, will apply themselves more energetically, and will remain on the job longer. ${ }^{93}$

Bureau officials also try to persuade workers seeking a new position to remain at their present jobs, rather than changing. Of those applying to the Ufa Bureau in 1971, 66.5 percent returned to their former jobs following their interviews. ${ }^{94}$ Whether these individuals were disappointed that no more suitable employment opportunities were available, were deliberately discouraged by bureau officials, or found some new reason to be enthusiastic about their old jobs, is unclear. Thus, we cannot say with certainty how much the centers help to raise industrial morale-if, indeed, they help at all.

The final approach in wide use is directed toward stimulating industrial democracy. Ever since the elimination of the "Workers' Opposition" movement half a century ago, workers in the USSR have had virtually no influence over their own wages or working conditions. In the past few years, however, a number of Soviet analysts have acknowledged that this circumstance gives rise to feelings of powerlessness, which in turn present a major barrier to job satisfaction. They argue that industrial morale will improve only if a more democratic "microclimate" is established at individual enterprises-only if, that is, "everybody,

90. See Radio Moscow broadcast of December 28, 1973, as reported in Foreign Broadcast Information Service, Daily Report: Soviet Union, January 10, 1974, pp. S 4-5. See also Trud, April 11, 1975, p, 2.

91. Trud, March 1, 1974, p. 2.

92. Sotsialisticheskaia industriia, July 11, 1973, p. 2. See also Trud, May 11, 1974, p. 2.

93. Sotsialisticheskaia industriia, July 11, 1973, p. 2.

94. Ibid. 
regardless of his position, feels that he is significant and necessary." "9ome labor specialists have urged that workers be permitted, or even encouraged, to become involved in official discussions of production problems at their enterprise. ${ }^{96}$ Others contend that it is necessary for rank-and-file workers to acquire "a sense of ownership," and have therefore called for worker participation in the planning and management of industrial affairs. Only in this way will the worker feel "that he is not a visitor in whose presence there is a reluctance to discuss problems or shortcomings, but rather an owner who must himself meet these problems with a solution." 97 Such proposals involve bringing ordinary workers into the decision-making process in individual shops and factories, thus encouraging them to help eliminate production bottlenecks and to participate in the setting of work norms and wage rates. Workers might suggest which products should be submitted for the Seal of Quality, and even recommend who should be rewarded, penalized, or promoted. ${ }^{98}$

A number of Soviet commentators have spoken out forcefully on the need for fundamental changes in the sphere of labor-management relations. Two labor specialists have written:

The plan is fulfilled by people, and it is necessary to choose managers who are able to work with people and ensure an efficient rhythm in production without any kinds of psychological problems. A collective ... will never excuse cold indifference, callousness, rudeness, or anything else which is associated with the so-called "strict" style of management.98

Echoing these remarks, a philosopher has observed: "Good intentions are not enough. We must have a deep understanding of the psychology of the working man." If and when that day arrives, he adds, "the number of people who 'dislike work' will undoubtedly decrease tremendously."100 Perhaps the most eloquent expression of this theme comes from an article in Pravda: "friendship cannot be programed like the process for manufacturing some component. It is necessary to learn to understand people, to sense their moods, and to control one's own words and actions."101

Thus far, this viewpoint has stimulated more discussion than action. The typical manager remains "the commander of his collective."102 Of course, some effort has been made to persuade managerial personnel to be more sensitive to the needs and feelings of their subordinates. In several areas of the country, managers are being trained in industrial psychology. In other areas, administrators are being instructed in "the fundamentals of production pedagogy."103

95. Sotsialisticheskaia industriia, September 26, 1973, p. 3.

96. Literaturnaia gazeta, May 16, 1973, p. 10.

97. Trud, May 30,1972, p. 2.

98. Komsomol'skaia pravda, March 27, 1973, p. 2.

99. Pravda, July 30, 1973, p. 2.

100. Literaturnaia gazeta, May 16, 1973, p. 10.

101. Trud, May 30, 1972, p. 2. See also Izvestiia, March 11, 1973, p. 3.

102. Pravda, July 30,1973 , p. 2.

103. Sovetskaia Estoniia, February 16, 1972, p. 2; Trud, May 30, 1972, p. 2; Ekonomicheskaia gazeta, 1974, no. 31, p. 7. 
Some officials claim that such programs have resulted in a "sharp decrease" in labor productivity whenever they are introduced, ${ }^{104}$ but very little evidence has been presented in support of this contention.

Other approaches are utilized in various regions of the country. In some factories, young workers are assigned to older, more experienced "mentors" or "tutors" (nastavniki). Each "tutor" is supposed to "impart to the young person his skill and his worker's ethic," stimulating loyalty to the plant and encouraging feelings of job satisfaction. ${ }^{105}$ Several enterprises have introduced an elaborate ceremony to greet new workers; the objective here, too, is to help engender feelings of pride and loyalty. ${ }^{106}$ Factories everywhere continue to build large numbers of new apartments, day-care centers, and other facilities which people vitally need, but the facilities are not put up quickly enough to satisfy the massive and continually growing demand, and they frequently are of low quality.

The economic and social costs of labor turnover clearly have generated considerable concern among Soviet economists and planners. To date, the various programs and proposals designed to reduce labor turnover-including vocational guidance programs, various material and nonmaterial incentives, making enterprises more attractive and safer, establishing employment bureaus, and stimulating industrial democracy-have had relatively little impact on the problem. Whether or not continued experience with these programs will make a difference in the future-or whether new approaches will have to be devised-remains to be seen.

104. Planovoc khosiaistvo, 1973 , no. 11, p. 21.

105. Pravda Ukrainy, March 24, 1974, p. 2. For the fullest explication of the nature and purpose of the "tutorship" program, see Kommunist, 1975, no. 2, pp. 55-64.

106. See Turkmenskaia iskra, May 12, 1973, p. 2. 